\title{
Development of Multimedia-Based Learning Media at MA Muhammadiyah 1 Malang
}

\author{
Pengembangan Media Pembelajaran Berbasis Multimedia \\ di MA Muhammadiyah 1 Malang
}

\author{
Nathasa Pramudita Irianti \\ Universitas Tribhuwana Tunggadewi \\ Jalan Telaga Warna, Tlogomas, \\ Malang \\ nathasa1990@gmail.com
}

\author{
Hasminar Rachman Fidiastuti \\ Universitas Tribhuwana Tunggadewi \\ Jalan Telaga Warna, Tlogomas, \\ Malang \\ indo.hasminar@gmail.com
}

\author{
Antonius Alam Wicaksono \\ Universitas Tribhuwana Tunggadewi \\ Jalan Telaga Warna, Tlogomas, \\ Malang \\ antonius.educator@gmail.com
}

\begin{abstract}
This research is a development research that aims to develop multimedia-based learning media in mathematics. The material used is Three Dimensional material. After the multimedia-based learning media has been designed, content validation tests are carried out, media expert validation tests, user validation tests (teachers), and limited tests (students). The results of media expert validation showed an average score of $61.8 \%$ and was included in the appropriate criteria. The results of the material expert validation showed an average score of $80 \%$ and was included in the appropriate criteria. The user (teacher) validation test showed an average score of $91.25 \%$ and was included in the appropriate criteria. In the limited test stage (students) as many as 25 students at MA Muhammadiyah 1 Malang produced an average score of $82.01 \%$ and were included in the appropriate criteria. Based on the results of all media validation carried out, the average feasibility of this multimedia-based learning media is $78.76 \%$ and according to the eligibility criteria, this multimedia-based learning media is declared feasible and can be used by students as additional media in learning Three Dimensional material.
\end{abstract}

Keywords: development, learning media, multimedia

Abstrak

Penelitian ini adalah penelitian pengembangan yang bertujuan untuk mengembangkan media pembelajaran berbasis Multimedia pada mata pelajaran matematika. Materi yang digunakan adalah materi Dimensi Tiga. Setelah media pembelajaran berbasis multimedia telah selesai dirancang, dilakukan uji validasi isi materi, uji validasi ahli media, uji validasi pengguna (guru), dan uji terbatas (siswa). Hasil validasi ahli media menunjukkan rata-rata skor $61,8 \%$ dan masuk dalam kriteria layak. Hasil validasi ahli materi menunjukkan rata-rata skor $80 \%$ dan masuk dalam kriteria layak. Uji validasi pengguna (guru) menunjukkan hasil rata-rata skor $91,25 \%$ dan termasuk dalam kriteria layak. Dalam tahap uji terbatas (siswa)sebanyak 25 siswa di MA Muhammadiyah 1 Malang menghasilkan rata-rata skor $82,01 \%$ dan termasuk dalam kriteria layak. Berdasarkan hasil dari seluruh validasi media yang dilakukan tersebut, rata-rata kelayakan media pembelajaran berbasis multimedia ini yaitu sebesar $78,76 \%$ dan sesuai dengan kriteria kelayakan, media pembelajaran berbasis multimedia ini dinyatakan layak dan dapat digunakan siswa sebagai media tambahan dalam belajar materi Dimensi Tiga.

Kata kunci: pengembangan, media pembelajaran, multimedia

Corresponding author: Nathasa Pramudita Irianti (08563443483)

\section{PENDAHULUAN}

Pandemi COVID-19 telah mempengaruhi segala bidang, tidak terkecuali dalam bidang Pendidikan. Di Indonesia sendiri, Pandemi Covid-19 yang menyerang sejak Maret 2020, berpengaruh pada semua bidang, termasuk juga dalam aspek pendidikan(Irianti \& Wicaksono, 2021). Pemerintah melalui Kemendikbud segera tanggap dengan mengambil beberapa kebijakan dalam bidang pendidikan. Bapak Nadiem Makarim mengambil kebijakan terkait masalah Covid19 dalam dunia Pendidikan dengan mengeluarkan edaran untuk berubahnya sistem pembelajaran 
dari tingkat dasar hingga perguruan tinggi menjadi sistem pembelajaran secara online (daring). Dalam surat edaran tersebut, Bapak Menteri meminta agar seluruh pembelajaran tidak lagi dilakukan secara tatap muka di kelas, namun secara online sejak edaran tersebut dikeluarkan (Kementerian Pendidikan dan Kebudayaan Republik Indonesia, 2020). Upaya ini dilakukan sebagai usaha untuk memperlambat penyebaran COVID-19.

Pembelajaran daring memberikan manfaat di antaranya adalah hilangnya batasan ruang dalam belajar (Ahmed, 2018). Sayangnya, pembelajaran online (daring) yang dilakukan siswa dari tempat masing-masing juga menimbulkan beberapa masalah bagi siswa. Salah satunya adalah minat belajar mandiri siswa yang menurun. Matematika yang dirasa sulit bagi siswa, menjadi semakin berat karena harus dilaksanakan secara daring(Irianti, 2020). Hal ini sesuai dengan hasil wawancara dengan Guru Matematika di MA Muhammadiyah 1 Malang yang menyatakan bahwa pembelajaran matematika menjadi kurang efektif karena dilakukan secara online (daring). Menurutnya, pembelajaran matematika seharusnya dilaksanakan secara tatap muka agar dapat membantu siswa secara maksimal ketika menemui kendala dalam proses pembelajarannya. Selama ini, media yang dipakai di MA Muhammadiyah 1 Malang dalam pembelajaran matematika media PowerPoint yang dapat diakses oleh siswa melalui Google Classroom.

Materi Dimensi Tiga merupakan salah satu materi matematika yang diajarkan di kelas $\mathrm{X}$. materi dimensi tiga ini menjadi salah satu materi yang menimbulkan masalah bagi sebagian besar siswa. Materi dimensi tiga yang kebanyakan berbentuk abstrak, menjadi sulit untuk dibayangkan (Novita et al., 2018). Hal ini semakin memperparah pembelajaran matematika yang harus dilaksanakan secara online (daring) selama masa pandemi.

Salah satu solusi yang dapat diberikan untuk masalah ini adalah dengan memberikan suplemen pendamping siswa dalam melaksanakan proses pembelajaran matematika khususnya pada materi dimensi tiga. Salah satu cara yang bisa dilakukan adalah dengan menambah media belajar siswa yang dapat mereka pelajari secara mandiri dengan mengemas materi menjadi lebih konkrit dan lebih mudah untuk dipahami. Salah satu media pembelajaran yang dapat digunakan dalam pembelajaran daring ini adalah media pembelajaran berbasis multimedia (Baharuddin, 2015). Menurut Niken dan Haryanto, media pembelajaran berbasis multimedia pemanfaatan teknologi sebagai media pembelajaran yang dapat dioperasikan secara mandiri oleh pengguna yaitu siswa, sehingga siswa dapat melaksanakan pembelajaran mandiri menjadi lebih efektif (Niken \& Haryanto, 2012). Menambahkan, dari penelitian yang dilakukan oleh Triayomi, menunjukkan bahwa media pembelajaran multimedia juga dapat digunakan sebagai pendamping siswa dalam mempelajari materi dimensi tiga (Triayomi, 2019).

Berdasarkan latar belakang tersebut penelitian ini bertujuan untuk mengembangkan media pembelajaran berbasis multimedia yang dapat digunakan siswa sebagai pendamping dalam belajar matematika khususnya materi dimensi tiga.

\section{METODE}

Penelitian pengembangan ini di adaptasi dari model pengembangan oleh Sadiman yang terdiri dari sembilan tahapan (Sadiman, 2014). Sembilan tahapan tersebut di antaranya adalah (1) Identifikasi masalah, (2) Merumuskan Tujuan, (3) Pengembangan Materi, (4) Pengembangan Alat Evaluasi, (5) Penyusunan Naskah, (6) Produksi, (7) Petunjuk Pemanfaatan, (8) Validasi, dan (9) Revisi.

Instrumen yang digunakan pada penelitian ini berupa angket/kuesioner. Selanjutnya, data yang didapatkan dianalisis dengan Teknik analisis data sebagai berikut.

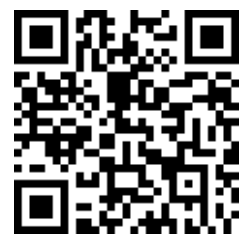

DOI PUBLIKASI https://doi.org/10.37010/int.v2i2 


\section{Nathasa Pramudita Irianti, Hasminar Rachman Fidiastuti, Antonius Alam Wicaksono}

Universitas Tribhuwana Tunggadewi

Keterangan:

$$
P=\frac{\sum x}{n} \times 100 \%
$$

$P \quad=$ Persentase skor

$\sum x=$ Jumlah jawaban tiap responden dari item pertanyaan

$n \quad=$ Total skor jawaban jika seluruh responden menjawab benar

Untuk menentukan kualifikasi kelayakan software media pembelajaran yang dikembangkan, digunakan kriteria sebagai berikut.

Tabel 1. Kriteria Kelayakan

\begin{tabular}{cc}
\hline Persentase & Kriteria \\
\hline $76 \%-100 \%$ & Layak \\
$56 \%-75 \%$ & Cukup Layak \\
$40 \%-55 \%$ & Kurang Layak \\
$<40 \%$ & Tidak Layak \\
\hline
\end{tabular}

Sumber: Arikunto (2019)

\section{HASIL DAN PEMBAHASAN}

\section{Hasil}

Hasil pengembangan media adalah berupa sebuah program pembelajaran Dimensi Tiga kelas X semester dua. Dalam media pembelajaran yang dikembangkan terdapat animasi jarak dan sudut dalam bangun ruang yang juga disertai contoh pada setiap materi. Selain terdapat animasi dalam materi, pada setiap pokok bahasan jarak dan sudut diberikan apersepsi yang juga berupa animasi. Media pembelajaran ini dilengkapi dengan beberapa contoh soal dan simulasi agar siswa lebih paham mengenai jarak dan sudut dalam dimensi tiga. Pada beberapa contoh soal, siswa dibantu dengan jawaban yang dikemas dalam bentuk video. Dengan adanya animasi dan video yang terdapat dalam media yang dikembangkan, para siswa lebih mudah dan tertarik untuk belajar, karena dengan adanya animasi dan video siswa mendapatkan visualisasi yang jelas dari materi Dimensi Tiga.

Di dalam media pembelajaran ini terdapat tampilan utama. Pada tampilan utama ini terdapat lima tombol menu utama, yaitu tombol pengantar, materi, contoh soal, simulasi, dan evaluasi. Terdapat juga dua tombol kecil di sebelah kiri bawah, yaitu tombol (X) exit dan tombol (panah atas) menu utama.

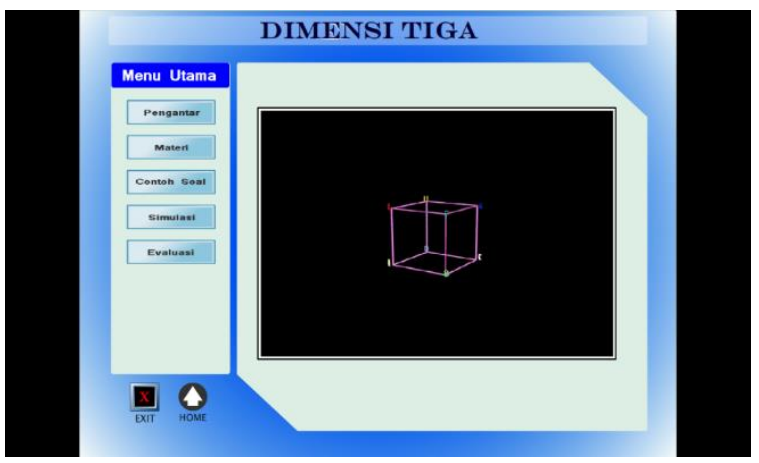

Sumber: Pribadi (2021)

Gambar 1. Tampilan Utama Media Pembelajaran 


\section{Pembahasan}

Uji kelayakan media pembelajaran yang telah dikembangkan dilaksanakan dan telah divalidasi oleh dua Dosen Universitas Tribhuwana Tunggadewi yang ahli pada bidangnya, satu Guru mata pelajaran Matematika MA Muhammadiyah 1 Malang, serta 25 siswa MA Muhammadiyah 1 Malang. Uji kelayakan yang digunakan yaitu uji validasi isi materi, uji validasi ahli media, uji validasi pengguna (guru), dan uji terbatas (siswa).

Dalam uji validasi konstruksi ini divalidasi oleh Dosen dari Universitas Tribhuwana Tunggadewi yang berkompeten dan ahli dalam multimedia.

Tabel 2. Rata-rata Persentase Penilaian Validator terhadap Konstruksi Media Pembelajaran Dimensi Tiga

\begin{tabular}{|c|c|c|c|}
\hline No. & Aspek yang Dinilai & $\begin{array}{l}\text { Rata-rata } \\
(\%)\end{array}$ & Kriteria \\
\hline 1. & $\begin{array}{l}\text { Terdapat Identitas pembelajaran (seperti standar kompetensi, } \\
\text { kompetensi dasar, dll) }\end{array}$ & 75 & Layak \\
\hline 2. & Kesesuaian materi dengan identitas pembelajaran & 75 & Layak \\
\hline 3. & $\begin{array}{l}\text { Kemampuan program untuk membuka peluang dalam } \\
\text { mengembangkan berpikir konstruktivis siswa }\end{array}$ & 50 & $\begin{array}{l}\text { Cukup } \\
\text { Layak }\end{array}$ \\
\hline 4. & Kejelasan isi materi dan kalimat yang digunakan & 50 & $\begin{array}{l}\text { Cukup } \\
\text { Layak }\end{array}$ \\
\hline 5. & Kemenarikan gambar dan animasi yang digunakan & 50 & $\begin{array}{l}\text { Cukup } \\
\text { Layak }\end{array}$ \\
\hline 6. & Kesesuaian animasi dengan materi yang disajikan & 50 & $\begin{array}{l}\text { Cukup } \\
\text { Layak }\end{array}$ \\
\hline 7. & Mudah dalam pengoperasian program & 75 & Layak \\
\hline 8. & Interaktif dalam penyampaian materi & 50 & $\begin{array}{l}\text { Cukup } \\
\text { Layak }\end{array}$ \\
\hline 9. & Kemenarikan warna yang digunakan & 75 & Layak \\
\hline 10. & Kemenarikan gambar/ visual yang digunakan & 50 & $\begin{array}{l}\text { Cukup } \\
\text { Layak }\end{array}$ \\
\hline 11. & Kemenarikan penyajian visual animasi yang digunakan & 50 & $\begin{array}{l}\text { Cukup } \\
\text { Layak }\end{array}$ \\
\hline $\begin{array}{l}12 . \\
13 .\end{array}$ & $\begin{array}{l}\text { Petunjuknya sederhana dan mudah dipahami } \\
\text { Ukuran dan jenis huruf mudah untuk dibaca }\end{array}$ & $\begin{array}{l}75 \\
75\end{array}$ & $\begin{array}{l}\text { Layak } \\
\text { Layak }\end{array}$ \\
\hline 14. & Isi dalam satu layar tampilan tidak terlalu padat & 50 & $\begin{array}{l}\text { Cukup } \\
\text { Layak }\end{array}$ \\
\hline 15. & $\begin{array}{l}\text { Tampilan fokus pada satu hal ( tulisan, gambar, dan animasi tidak } \\
\text { muncul bersamaan) }\end{array}$ & 75 & Layak \\
\hline 16. & $\begin{array}{l}\text { Kombinasi warna antara tulisan, background dan gambar sesuai dan } \\
\text { menarik }\end{array}$ & 75 & Layak \\
\hline 17. & Tombol dan desain layar konsisten ( tidak berubah-ubah) & 75 & Layak \\
\hline 18. & Satu tampilan layar memuat pokok bahasan yang utuh & 50 & $\begin{array}{l}\text { Cukup } \\
\text { Layak }\end{array}$ \\
\hline 19. & Kesesuaian penggunaan komputer dengan jenis evaluasi (esai) & 50 & $\begin{array}{l}\text { Cukup } \\
\text { Layak }\end{array}$ \\
\hline \multicolumn{2}{|r|}{ Rata-rata kelayakan } & 61,8 & $\begin{array}{l}\text { Cukup } \\
\text { Layak }\end{array}$ \\
\hline
\end{tabular}

Sumber: Diolah (2021)

Berdasarkan tabel di atas, dapat dilihat bahwa dari 19 indikator penilaian yang diberikan, ada 10 indikator yang mendapatkan persentase $50 \%$ yaitu kemampuan dalam mengonstruksi pemikiran siswa, isi materi dan kalimat jelas, gambar dan animasi menarik, animasi sesuai 
dengan materi, interaktif, gambar/ visual menarik, visualisasi animasi menarik, tampilan tidak terlalu padat, tampilan memuat materi yang utuh, serta kesesuaian untuk soal evaluasi. Sedangkan sisanya yaitu 9 indikator mendapatkan persentase $75 \%$, yaitu terdapat identitas pembelajaran, materi sesuai dengan identitas pembelajaran, mudah pengoperasian, warna menarik, petunjuk sederhana dan mudah dipahami, ukuran dan jenis huruf mudah dibaca, tampilan fokus pada satu hal, kombinasi warna sesuai dan menarik, serta tombol dan desain konsisten. Dari seluruh indikator diperoleh rata-rata persentase kelayakan sebesar 61,8. Berdasarkan kriteria kelayakan yang ada, mendapatkan kriteria cukup layak yang berarti bisa disajikan untuk penjelasan materi dalam pembelajaran.

Dalam uji validasi isi, media pembelajaran ini divalidasi oleh Dosen dari Universitas Tribhuwana Tunggadewi yang berkompeten dan ahli dalam materi Dimensi Tiga.

Tabel 3. Rata-rata Persentase Penilaian Validator terhadap Materi Media Pembelajaran Dimensi Tiga

\section{Aspek yang Dinilai}

\begin{tabular}{llcc}
\hline No. & \multicolumn{1}{c}{ Aspek yang Dinilai } & Rata-rata & Kriteria \\
\hline 1. & Materi yang dijelaskan sesuai standar kompetensi. & $(\boldsymbol{\%})$ & Layak \\
2. & Materi yang dijelaskan sesuai kompetensi dasar. & 100 & Layak \\
3. & Materi yang dijelaskan sesuai tujuan belajar. & 75 & Layak \\
4. & Materi sesuai konsep dan teori yang benar. & 75 & Layak \\
5. & Terdapat petunjuk pengoperasian media & 100 & Layak \\
6. & Definisi dapat dipahami. & 75 & Layak \\
7. & Penyampaian bertahap, sesuai kemampuan siswa. & 75 & Layak \\
8. & Animasi dan gambar sesuai materi & 75 & Layak \\
9. & Memberikan penekanan pada konsep penting (cetak tebal) & 75 & Layak \\
10. & Sajian materi memuat masalah yang dapat merangsang pemikiran & 75 & Layak \\
& siswa. & 75 & Layak \\
11. & Kejelasan susunan kalimat. & 100 & Layak \\
12. & Satu pengertian materi ditampilkan dalam satu layar & 75 & Layak \\
13. & Contoh soal mudah dipahami. & 75 & Layak \\
14. & Contoh soal berkembang terurut dari yang mudah ke yang sukar & 75 & Layak \\
15. & Penyajian materi bersifat interaktif untuk memotivasi siswa. & 75 & Layak \\
16. & Tingkatan bahasa pada materi sesuai dengan kemampuan siswa. & 75 & Layak \\
17. & Kemenarikan visualisasi animasi dalam materi & 75 & Layak \\
18. & Kejelasan animasi, gambar, dan tulisan. & 75 & Layak \\
19. & Warna pada tulisan, gambar, dan animasi jelas dan nyaman dilihat & 75 & Layak \\
20. & Ukuran huruf sesuai sehingga jelas dibaca & 75 & Layak \\
21. & Isi dalam satu layar tampilan tidak terlalu padat & 75 & Layak \\
22. & Tampilan fokus pada satu hal ( tulisan, gambar, dan animasi tidak & 75 & Layak \\
23. & muncul bersamaan) & 75 & Layak \\
24. & Bahasa yang digunakan baku \\
25. & Pembelajaran tidak panjang hingga membosankan untuk siswa & Layak \\
\hline & & 75 &
\end{tabular}
Rata-rata kelayakan

Berdasarkan Tabel 3 dapat dilihat bahwa dari 25 indikator penilaian yang diberikan, ada 5 indikator yang mendapatkan persentase $100 \%$ yaitu kesesuaian materi dengan standar kompetensi, kesesuaian materi dengan kompetensi dasar, adanya petunjuk pengoperasian media, tampilan materi utuh, serta pengoperasian media yang mudah. Sedangkan 20 indikator lainnya mendapatkan persentase $75 \%$, yaitu Materi sesuai tujuan pembelajaran, materi sesuai konsep dan teori yang benar, definisi dapat dipahami, penyampaian bertahap, animasi dan gambar sesuai 
materi, memberikan penekanan pada konsep penting, memuat masalah yang dapat merangsang pemikiran siswa, kejelasan susunan kalimat, contoh soal mudah dipahami, contoh soal berurut dari yang mudah ke sukar, interaktif dalam memotivasi siswa, tingkatan bahasa sesuai untuk siswa, visualisasi animasi menarik, animasi gambar dan tulisan jelas, warna yang digunakan nyaman dilihat, ukuran huruf mudah terbaca, tampilan tidak terlalu padat, tampilan fokus pada satu hal, bahasa baku, serta pembelajaran tidak membosankan. Dari seluruh indikator diperoleh rata-rata persentase kelayakan sebesar 80. Berdasarkan kriteria kelayakan yang ada, mendapatkan kriteria layak yang berarti bisa disajikan untuk penjelasan materi dalam pembelajaran.

Dalam uji validasi pengguna ini divalidasi oleh Guru dari MA Muhammadiyah 1 Malang yang berpengalaman mengajar matematika.

Tabel 4. Rata-rata Persentase Penilaian Validator terhadap Penggunaan Media Pembelajaran Dimensi Tiga

\begin{tabular}{llcc}
\hline No. & \multicolumn{1}{c}{ Aspek yang Dinilai } & $\begin{array}{c}\text { Rata-rata } \\
(\%)\end{array}$ & Kriteria \\
\hline 1. & Materi yang dijelaskan sesuai standar kompetensi. & 100 & Layak \\
2. & Materi yang dijelaskan sesuai kompetensi dasar. & 100 & Layak \\
3. & Materi yang dijelaskan sesuai tujuan belajar. & 100 & Layak \\
4. & Materi sesuai konsep dan teori yang benar. & 100 & Layak \\
5. & Definisi dapat dipahami. & 75 & Layak \\
6. & Penyampaian bertahap, sesuai kemampuan siswa. & 75 & Layak \\
7. & Animasi dan gambar sesuai materi & 100 & Layak \\
8. & Sajian materi memuat masalah yang dapat merangsang pemikiran & 75 & Layak \\
& siswa. & 75 & Layak \\
9. & Kejelasan susunan kalimat. & 50 & Layak \\
10. & Contoh soal mudah dipahami. & 100 & Layak \\
11. & Contoh soal berkembang terurut dari yang mudah ke yang sukar & 100 & Layak \\
12. & Penyajian materi bersifat interaktif untuk memotivasi siswa. & 100 & Layak \\
13. & Tingkatan bahasa pada materi sesuai dengan kemampuan siswa. & 100 & Layak \\
14. & Kemenarikan visualisasi animasi dalam materi & 100 & Layak \\
15. & Kejelasan animasi, gambar, dan tulisan. & 100 & Layak \\
16. & Warna pada tulisan, gambar, dan animasi jelas dan nyaman dilihat & 100 & Layak \\
17. & Ukuran huruf sesuai sehingga jelas dibaca & 100 & Layak \\
18. & Mudah dalam menggunakannya & 100 & Layak \\
19. & Bahasa yang digunakan baku & 75 & Layak \\
20. & Pembelajaran tidak panjang hingga membosankan untuk siswa & 91,25 & Layak \\
\hline & & Rata-rata kelayakan
\end{tabular}

Sumber: Diolah (2021)

Berdasarkan Tabel 4 dapat dilihat bahwa dari 20 indikator penilaian yang diberikan, ada 1 indikator yang mendapatkan persentase $50 \%$, yaitu contoh soal mudah dipahami. Ada 5 indikator yang mendapatkan persentase $75 \%$ yaitu definisi mudah dipahami, penyampaian bertahap sesuai kemampuan, materi memuat masalah yang dapat merangsang pemikiran siswa, kejelasan isi kalimat, serta pembelajaran tidak panjang dan membosankan. Sedangkan sisanya ada 14 indikator yang mendapat persentase $100 \%$. Dari seluruh indikator diperoleh rata-rata persentase kelayakan sebesar 91,25\%. Berdasarkan kriteria kelayakan yang ada, mendapatkan kriteria layak yang berarti bisa disajikan untuk penjelasan materi dalam pembelajaran.

Dalam uji validasi terbatas ini digunakan 25 siswa MA Muhammadiyah 1 Malang. Data uji kelayakan yang diperoleh berupa persentase rata-rata dan hasil tanggapan. 
Tabel 5. Rata-rata Persentase Penilaian Uji Terbatas terhadap Media Pembelajaran Dimensi Tiga

\begin{tabular}{llcc}
\hline No. & Aspek yang Dinilai & $\begin{array}{l}\text { Rata-rata } \\
(\mathbf{\%})\end{array}$ & Kriteria \\
\hline 1. & Meningkatkan motivasi belajar siswa & 89,5 & Layak \\
2. & Anda dilibatkan secara aktif ketika belajar menggunakan media ini & 83 & Layak \\
3. & Kejelasan isi materi dan kalimat yang digunakan & 81,4 & Layak \\
4. & Mudah dalam pengoperasian program & 78,2 & Layak \\
5. & Membantu meningkatkan pemahaman terhadap materi yang disajikan & 85,4 & Layak \\
6. & Kemenarikan gambar dan animasi yang digunakan & 81,4 & Layak \\
7. & Animasi jelas dan sesuai dengan penjelasan materi & 84,6 & Layak \\
8. & Ilustrasi cerita yang digunakan membantu Anda dalam memahami & 79,8 & Layak \\
& materi yang akan disampaikan & 79 & Layak \\
9. & Warna antara tulisan dan background kontras, sehingga Anda mudah & 79 & Layak \\
\cline { 2 - 4 } 10. & membaca isi materi & 77,4 & Layak \\
\hline & $\quad$ Rata-rata kelayakan huruf membuat Anda mudah membaca isi materi & 82,01 & \\
\hline Sumber: Diolah (2021) & &
\end{tabular}

Tabel 5 menunjukkan hasil uji terbatas media pembelajaran kepada siswa kelas eksperimen, yaitu 25 siswa MA Muhammadiyah 1 Malang. Uji kelayakan ini meliputi 10 indikator yang perlu dinilai. Persentase yang diperoleh dari rata-rata penilaian siswa yaitu meningkatkan motivasi belajar $89,5 \%$, keaktifan siswa dalam media $83 \%$, kejelasan isi materi dan kalimat $81,4 \%$, mudah pengoperasian $78,2 \%$, meningkatkan pemahaman $85,4 \%$, kemenarikan gambar dan animasi $81,4 \%$, kesesuaian animasi dan materi $84,6 \%$, apersepsi membantu memahami materi $79,8 \%$, kesesuaian warna tulisan dan background $79 \%$, dan kesesuaian ukuran huruf $77,4 \%$. Hasil uji kelayakan media pembelajaran ini diperoleh persentase rata-rata sebesar $82,01 \%$ Hal ini berarti media pembelajaran yang dikembangkan ini sudah layak untuk digunakan.

Berdasarkan hasil dari seluruh validasi media yang dilakukan, rata-rata kelayakan media yaitu sebesar 78,76 dengan kriteria layak. Hasil rata-rata kelayakan media secara keseluruhan dapat dilihat pada Tabel 6 berikut ini.

Tabel 6. Rata-rata Kelayakan terhadap Media Pembelajaran Dimensi Tiga

\begin{tabular}{|c|c|c|c|}
\hline No. & Validator & Rata-rata (\%) & Kriteria \\
\hline 1. & Ahli media & 61,8 & Layak \\
\hline 2. & Ahli materi & 80 & Layak \\
\hline 3. & Pengguna (guru) & 91,25 & Layak \\
\hline 4. & Uji terbatas (siswa) & 82,01 & Layak \\
\hline & Rata-rata kelayakan & 78,76 & Layak \\
\hline
\end{tabular}

Sumber: Diolah (2021)

\section{PENUTUP}

Setelah media pembelajaran berbasis multimedia telah selesai dirancang, kemudian dilakukan validasi. Uji kelayakan yang digunakan yaitu uji validasi isi materi, uji validasi ahli media, uji validasi pengguna (guru), dan uji terbatas (siswa). Hasil validasi ahli media menunjukkan rata-rata $61,8 \%$ dengan kriteria layak. Hasil validasi ahli materi menunjukkan ratarata $80 \%$ dengan kriteria layak. Uji validasi pengguna (guru) menunjukkan hasil rata-rata 91,25\% dengan kriteria layak. Dalam tahap uji terbatas (siswa) menghasilkan rata-rata 82,01\% dengan 
kriteria layak. Berdasarkan hasil dari seluruh validasi media yang dilakukan, rata-rata kelayakan media yaitu sebesar 78,76 dengan kriteria layak. Berdasarkan hasil tersebut, media pembelajaran berbasis multimedia ini dapat digunakan sebagai pendamping oleh siswa dalam belajar matematika, khususnya pada materi dimensi tiga.

\section{DAFTAR PUSTAKA}

Arif S. Sadiman, dkk. (2014). Media Pendidikan: pengertian, pengembangan dan pemanfaatannya. Depok: PT. Raja Grafinso Persada

Arikunto, S. (2019). Prosedur Penelitian. Jakarta: Rineka Cipta

Baharuddin. (2015). Pengembangan Media Pembelajaran Berbasis Multimedia Interaktif Sekolah Menengah Kejuruan terhadap Efektif dan Efisiensi Pembelajaran. Jurnal Inovasi dan Teknologi Pembelajaran, 1(2), 115-126

Pilkington, O. A. (2018). Active Learning for an Online Composition Classroom: Blogging as an Enhancement of Online Curriculum. Journal of Educational Technology Systems, 47(2), $1-14$

Irianti, N. P. (2020). Analisis Kemampuan Penalaran Siswa dalam Memecahkan Masalah Matematika Berdasarkan Langkah-Langkah Polya. MUST: Journal of Mathematics Education, Science and Technology, 5(1), 80. https://doi.org/10.30651/must.v5i1.3622

Irianti, N. P., \& Wicaksono, A. A. (2021). Pengembangan media E-Learning Berbasis Web untuk Mata Pelajaran Matematika. Jurnal MathEducation Nusantara, 4(1), 1-9.

Novita, R., Prahmana, R. C. I., Fajri, N., \& Putra, M. (2018). Penyebab kesulitan belajar geometri dimensi tiga. Jurnal Riset Pendidikan Matematika, 5(1), 18. https://doi.org/10.21831/jrpm.v5i1.16836

Triayomi, Ria. (2019). Pengembangan Media Pembelajaran Berbasis Multimedia Tiga Dimensi Bercode untuk Sekolah Dasar. Jurnal Inovasi Pendidikan, 9(2) 